\title{
Sekhukhune II and the Pedi Operations of the Anglo-Boer War, 1899-1902
}

\author{
Felix Malunga ${ }^{*}$
}

\section{Introduction}

In this paper an attempt will be made to demonstrate how the Pedi under the leadership of Sekhukhune II took advantage of wartime conditions during the Anglo - Boer War to reshape the pattern of colonial relations imposed on them by the Zuid-Afrikaansche Republiek, to attempt to re-establish the dominance of the Sekhukhune House in the eastern Transvaal and to negotiate favourable terms with the occupying British military forces once the ZAR was defeated.

It will also be shown that often Sekhukhune II deliberately followed a policy of not eliminating republican government officials, Boer farmers and their families as well as the Berlin missionaries in order not to antagonise the British and Boer military authorities against him. However, Sekhukhune II subjected all these groups to frequent harassment. Another primary aim of Sekhukhune II was to concentrate on punishing "sell-out usurpers" of the Pedi paramountcy who had betrayed the Pedi polity by pledging allegiance to Abel Erasmus, the Native Commissioner, who had represented Boer hegemony over the Pedi between 1881 and 1899.

Again, Sekhukhune II punished Pedi Christian converts of the Berlin missionary society who had abandoned and undermined Pedi traditions and culture by converting and adhering to Christian principles. In this respect, a number of Berlin mission stations became battlefields of the warring Pedi factions. In the process these mission stations were neutralised as centres of the Berlin missionary activities. It was only after 1902 that attempts were made by the missionary authorities to rebuild these mission stations.

\section{The main Pedi formations at the outbreak of war}

When the Anglo-Boer War broke out in 1899, the Pedi in the eastern Transvaal were split into three main groups occupying the country northeast of the Steelpoort and the Northern Middelburg district. The only Whites who lived in this area included the families of the Sub-Native Commissioner, W.R. Van der Wal, the missionary J.A Winter and a few White traders.

The first group consisting of the majority of the Pedi in Sekhukhuneland, as well as in the districts of Ohrigstad, Lydenburg, parts of the Middelburg district and some areas north of the Olifants River acknowledged Sekhukhune II as their hereditary paramount chief. ${ }^{2}$ The second

\footnotetext{
- Department of History, University of Venda.

1 Pretoria Archives Depository: archives of the Secretary for Native Affairs (hereinafter SNA) 7,182/02 J.H. Winter, "The Last Rising in Sekukuni's Land", 8.9.1900.

2 Lebowakgomo Library, Northern Province: Rev E. Motubase Collection (hereinafter K) 34,120/997(7), Motubatse, Vol 7, p 742.
} 


\section{Malunga}

group of the Pedi was under Chief Kgolane, a ZAR government appointed chief with a small following. This group occupied the southern half of Geluks Location with Masehleng village as their headquarters. Kgolane was a cousin of the late Sekhukhune I and was appointed regent in 1895 by the ZAR in the place of Sekhukhune II who was still a minor at the time. With the help of Erasmus and the Bapedi Lutheran Church, Kgolane had surreptitiously managed to split the Pedi paramountcy. When Sekhukhune II came of age in 1898, he demanded the re-unification of his kingdom and threatened to take military action against Kgolane who refused to step down as regent. However, at this point in time, no action was taken because Kgolane was still under the protection of the $\mathrm{ZAR}^{3}$

The third group was formed by followers of Chief Malekutu II who lived in the northern part of the district of Middelburg. Malekutu II was the son of Malekutu I who was hanged by the British in 1883 for assassinating Sekhukhune I. When Sekhukhune II took over the Pedi paramountcy, he vowed to revenge the death of his grandfather by destroying the chieftainship of Malekutu II ${ }^{4}$. However, followers of Malekutu II regarded the Sekhukhune House as usurpers of the Pedi paramountcy and vowed to defend themselves ${ }^{5}$. It was under these conditions that Sekhukhune II waited for an opportune time to subjugate his opponents. The outbreak of the war in 1899, which upset the republican government control over the Pedi, gave him the opportunity to undermine the authority of the ZAR in the area and launch attacks against his Pedi rivals.

When the war broke out in March 1899, the three Pedi factions briefly remained passive and maintained a low profile. They kept a close watch on the situation to see in whose favour the war would turn. The Native Commissioner, however, became apprehensive about the security of the white farming community in the Lydenburg district. At his request, Commandant Klaas Prinsloo was despatched with a strong force to the Pedi heartland (Sekhukhuneland) in October 1899. This commando was intended to prevent cattle-rustling, to conscript Pedi labour to work on the farms, to herd cattle of farmers on commando and to thwart any attempt by the Sekhukhune party to reestablish its control over Pedi affairs. In addition, many Swazi "native police" under chief Malepeng were engaged and armed by the ZAR government to tighten security in and around Geluks Location. $^{6}$

Apart from $£ 1$ poll tax, an additional levy of 2s 6d was imposed on each Pedi taxpayer in Geluks Location for the upkeep of the burger commando. The levy was collected on two occasions and each family was also ordered to provide the occupying commando with an ox. ${ }^{7}$ These impositions, coming too soon after the impoverishment of the Pedi through the drought of 1896 and the rinderpest disease which almost wiped out all their cattle, created tension between the majority of Pedi and the ZAR government.

\section{Sekhukhune II's first offensive against pro-ZAR Pedi chiefs}

Commandant Prinsloo's occupying commando was withdrawn from Sekhukhuneland soon after the occupation of Pretoria by the British forces in June 1900. The commando was to join and

UNISA Archives: Berlin Mission Society Archives (hereinafter BMB), August 1901,p 322.

Ibid., p 323.

K 34,120/997(7), Motubatse, Vol 7, p 742.

SNA 7,182/01, Winter, "The Last Rising in Sekukuni's Land", 8.9.1900.

Ibid.; BMB, August 1901,p.323. 
reinforce the retreating Boer forces that were under increasing military pressure in the Lydenbrug district. This left the opposing Pedi factions facing each other without a restraining military authority force. Young Sekhukhune II, fresh from circumcision, welcomed this opportunity to prove his chieftainship by engaging and defeating all his rivals. ${ }^{8}$ Correctly judging that the scales of war were shifting in favour of the British, Sekhukhune II launched attacks on his rivals and other collaborating clients of Erasmus.

Attempts by Sekhukhune II to restore the Pedi kingdom of his grandfather created a theatre of war in the eastern Transvaal among Pedi groups. Kgobalale, the military leader of the Sekhukhune party, spearheaded most of these attacks. First to be attacked was Kgolane. On the 10 June 1900, Sekhukhune II's spies infiltrated the unsuspecting crowd during a feast at Masehleng. They encouraged Kgolane's men to over indulge in beer drinking, while they themselves drank moderately. Thoroughly drunk, that night Kgolane's men lay fast asleep in their huts ${ }^{9}$. Kgobalale with 140 handpicked men left Mohlaletse, capital village of Sekhukhune II, by night to launch a surprise attack on Kgolane and his followers at Masehleng. The attacking warriors turned Kgolane's community into an inferno by setting the huts on fire. As Kgolane's men attempted to flee from the burning huts, they fell prey to Kgobalele's warriors who were waiting for them. ${ }^{10}$

In their drunken stupor, Kgolane's warriors were incapable of giving any real resistance. At the instructions of Sekhukhune II, all women and children were spared. They were rounded up and shepherded to Mohlaletse. ${ }^{11}$ Berlin missionaries mistakenly took this gesture as a positive sign of the impact of Christianity on Pedi chiefs. In reality, however, Sekhukhune II wanted these women and children as captives to increase the number of his followers.

Kgolane and some of his men managed to escape. However, eight of his subordinate chiefs and more than 200 of his followers were killed. ${ }^{12}$ During the attack on Kgolane, members of the Bapedi Lutheran Church at Masehleng, Khalatlou and elsewhere were also persecuted by Pedi warriors loyal to Sekhukhune II. Several of these Christians were actually killed for having supported the installation of Nkopodi and Kgolane by the ZAR in 1892 and 1985 respectively. Meanwhile the escaping Kgolane and his men managed to join the sub-Native Commissioner at Khalatlou where they requested protection. ${ }^{13}$

Afraid of the advancing warriors of Sekhukhune II, Van der Wal, a small commando under Commandant Prinsloo accompanied by Kgolane's followers and members of the Bapedi Lutheran Church all fled to Rietfontein. The office and house of Van der Wal which were seen as centres of the ZAR authority in Sekhukhuneland, were set alight and destroyed. The warriors were instructed not to eliminate republican government officials, traders, farmers and Berlin missionaries. Sekhukhune II assumed that by not attacking the Whites in Sekhukhuneland, the British and Boer military authorities would not interfere with his military campaigns. Nonetheless, Sekhukhune II's

\footnotetext{
8 Ibid.

9 Pretoria Archives Depository: Archives of the State Secretary ZAR (hereinafter SS) 4098,R1071/90, Winter to Native Commissioner, 14.6.1900.

$10 \quad$ Ibid.; BMB October 1900, p 600.

11 BMB, October 1900, p 601.

12 BMB, August 1901, pp 323-324.

13 BMB, July 1901, pp 269-270.
} 


\section{Malunga}

scouts closely monitored the movement of Van der Wal's group until they moved out of Sekhukhuneland.

Three days after the attack on Masehleng, Kgobalale attacked Rahlagane, a surbordinate chief of Kgolane. Rahlagane's settlement was completely destroyed and many of his men were killed. Phasoane, a pro-Sekhukhune II chief and his Batau in the southern half of Geluks Location also destroyed a pro-Kgolane settlement at Mangmang. Again in both instances, women and children were spared and taken captives. ${ }^{14}$

\section{Harassment of ZAR officials and Boer families}

A regiment led by Kgobalale visited Winter at his farm Onverwatchte. They demanded the surrender of all the cattle he had received for his work as Erasmus interpreter and tax collector. In addition three Mauser rifles, eight Martini rifles, 18 Mauser cartridges were confiscated. Tax money which Winter had collected from the Pedi on orders from Van der Wal was also repossessed by Kgobalale. ${ }^{15}$

During the same mission, Assaf Morutane, an advisor of Sekhukhune II, delivered a letter to Winter, which read as follows: "You know that for years long I do not live well in this land, which had been ours. I only see it, when it leaves me and belong to other people. Now, I will have it to be as in the old time. Again this has been said by God: You want an eye. From 1892 I was like a thief and evil doer in my land." ${ }^{, 16}$ Winter was ordered to transmit this message to the ZAR. This statement confirms the determination of Sekhukhune II to re-establish the authority of the Sekhukhune House throughout the eastern Transvaal.

The much-resented tax collectors and the Swazi "native police force" under Malepeng became an immediate target of vengeance by the Pedi. With the collapse of the authority of the ZAR in Sekhukhuneland, Kgobalale's men attacked Malepeng's settlement. All dwellings were destroyed. Cattle, goats and pigs were confiscated. Several men were reported killed during the confrontation. Malepeng and a number of his followers became fugitives. Malepeng was eventually arrested and executed in August 1900 by Kgobalale's men. ${ }^{17}$

The withdrawal of Commandant Prinsloo's commando from Lydenburg left Erasmus with no effective defence system. From now onwards Erasmus remained at the Lydenburg laager together with a few Boer families who had deserted their farms for fear of attack by the Pedi. Deprived of his political power and military back-up, Erasmus looked on with dismay as supporters of Sekhukhune II embarked on a campaign to punish all petty Pedi chiefs who had been being installed and supported the republican government against the Pedi paramountcy. The rank and file followers of these former petty chiefs now gave their allegiance to Sekhukhune II, thereby giving him complete control over the majority of the Pedi in Sekhukhuneland. ${ }^{18}$

SNA 50,1753/02, Sekhukhune II to Winter, 19.6.1900; P. Warwick, "Black People and the war" in P. Warwick and S.B. Spies (eds.) The South African War: The Anglo-Boer War, 1899-1902 (Longman: Harlow, 1980), p 193. 
Erasmus' position was further weakened when the majority of local farmers were called up for commando duties elsewhere in the republic. This enabled Sekhukhune II to assert his power throughout Sekhukhuneland without any effective opposition. However, Sekhukhune II made no attempt to attack the Lydenburg laager ${ }^{19}$. Apparently he believed that as long as he refrained from taking military action against ZAR citizens, the Boer military authorities would not launch counter attacks against him.

Sekhukhune II now claimed the paramountcy of the whole of the Pedi heartland. He set about establishing his authority over Pedi tenants and squatters who lived on company farms between the Olifants and Steelpoort rivers. In this regard Winter wrote: "No white man was allowed to use his cattle farms, no company had any authority left over their farms. In one case they [the Pedi] made this distinction: that the owner could use the fruit trees planted by him, but had no right to plant any more."20

Sekhukhune II also attacked Mafefe, chief of the Magokala who had supported Kgolane and Erasmus. Mafefe was driven across the Olifants River. The Boer officials in the Lydenburg district were soon compelled to accept the Steelpoort River as the eastern border between the Pedi and Boer territory. Sekhukhune II further instructed that all Pedi chiefs who had collaborated with the Erasmus administration should immediately pay tribute in the form of cattle or a young woman, in some cases both, to him as a symbol of their submission to his paramountcy. ${ }^{21}$ The chiefs grudgingly obliged because they realised that resistance would mean to continue war against Sekhukhune II. They would also have to do so without military help from the republican government that was attempting to repulse the British who were advancing on Pretoria.

\section{Berlin mission stations become zones of war among the Pedi}

Having subdued all pro-Kgolane chiefs in the Lydenburg district, Sekhukhune II now turned his attention to his second main rival, Malekutu II. He demanded that both Malekutu II and Kgolane should surrender and recognise him as their paramount chief. Both men rejected the demand and set about preparing themselves for the eminent attack on them by Sekhukhune II. This state of affairs troubled Paul Trupelmann, the missionary who was in charge of Lobethal mission station in the absence of Kadack who was trapped at Botshabelo mission station by the British and Boer forces. Other Pedi chiefs who lived in the immediate vicinity of Lobethal were Phala, Moreane and Tisane. Some of the followers of these chiefs were converted to Christianity and had settled at Lobethal. ${ }^{22}$

Sekhukhune II despatched his scouts to spy on the war preparations at Mamone. He also concluded an alliance with Phala and Moreane by which the three parties agreed to form a united front against Malekutu II. However, when Trupelmann confronted Phala and Moreane about their rumoured alliance with Sekhukhune II, they both denied knowledge of such an agreement. Trupelmann feared that such an alliance would turn Lobethal into a battle zone once hostilities

\footnotetext{
19 Ibid.

20 SNA 7,182/01, "The Last Rising"

21 SNA $1,475 / 01$, H.A. Junod, 'The story of the native war which occurred in the Lowveld from July to November 1900,' 19.6.1901; and SNA 50,1753/02, Sekhukhune II to Winter, n.d.

22 BMB, October 1900, pp 600-601; and BMB, August 1901.
} 


\section{Malunga}

broke out between Sekhukhune II and Malekutu II. Despite the denials by the 2 chiefs, general panic broke out at the mission station among Christians. A number of these Christians opted to take refuge in the surrounding mountain caves. ${ }^{23}$

Sekhukhune II's warriors subjected those who remained at the mission station to frequent harassment. One night in July 1900, Sekhukhune II's raiding party of warriors unexpectedly invaded the mission station and looted the maize and corn grains. The party also commandeered all cattle of Kadach to Mohlaletse. Trupelmann bravely rode after the raiding party and demanded the return of the livestock. Sekhukhune II ordered his arrest and for 2 days he was locked up in a hut after which he was set free and ordered to return to Lobethal. A few days later, to the surprise of Trupelmann and his Christians, all but two cattle were returned to him. The two cattle were actually slaughtered during a feast to honour Sekhukhune II's victorious warriors. ${ }^{24}$

Meanwhile Malekutu II concluded a military alliance with Tisane. The formation of this alliance impacted negatively on the stability of Lebethal mission station because the Christian community consisted of members from Malekutu, Tisane, Phala and Moreane. The result was that the Christian community at Lobethal was split into 2 opposing hostile camps - one supporting Sekhukhune II, Phala and Moreane and the other supporting Malekutu II and Tisane. Attempts by Trupelmann to unite the two camps and to negotiate an end to the dispute between Sekhukhune II and Malekutu II proved futile. ${ }^{25}$

On the 8 August 1900 Sekhukhune II's large army aided by regiments of his subordinate chiefs, launched an attack on Mamone. The attacking warriors outnumbered the warriors of Malekutu II and Tisane. The 2 chiefs abandoned their villages to their enemies and withdrew into the mountain fortresses where they were able to withstand the onslaught of Sekhukhune II's army $^{26}$. Malekutu II's people lost many of their livestock that were captured and taken as booty by the invading army. A Boer commando under C. Fourie, Native Commissioner of Middelburg district, managed with their superior firing power, to repulse Sekhukhune's army. When the latter withdrew from Mamone, Malekutu II and Kgolane went on the offensive. In the process, they managed to recapture some of the livestock from the retreating Sekhukhune II.

Meanwhile Lobethal mission station became a battlefield between the warriors of Tisane and Moreane who used the mission buildings for cover. The withdrawal of Sekhukhune II from Middelburg eventually led to the surrender of Moreane. Through Trupelmann, Moreane undertook voluntary subjugation to and recognition of Malekutu II as his paramount chief. However, Moreane was not honest and secretly continued to be in contact with Sekhukhune II. Both chiefs were actually planning a second attack on their enemies. When this was discovered, Malekutu II's warriors surrounded Moreane's village on the 29 August and besieged it for two days. Moreane was taken captive together with all his non-converted and Christian followers. His village was first looted and then set alight. Later Malekutu II executed Moreane, four of his sons and three councillors. However, Mokine, one of Moreane's sons, managed to escape and was later given

\footnotetext{
23 BMB October 1901, p 376.

24 Ibid.

$25 \quad$ BMB, August 1901, p 324.

26 SNA 7,182/01, "The last Rising"; and BMB July 1901, p 269.
} 
refuge by Sekhukhune II at Mohlaletse. A few weeks later, Malekutu II handed over Moreane's people to Chief Motsatsi whose father was once defeated and driven off his land by Moreane ${ }^{27}$.

When fighting eventually stopped at Lobethal, about 400 Christians were reported captured by the warring parties, more than 150 were reported dead and 20 critically wounded. The later had to be placed under the medical care of missionary Trumpelmann. The Christian community had lost almost all their maize and corn which was either confiscated or burnt by the warring warriors. Despite the cessation of hostilities at Lobethal, Christians continued to be apprehensive of Sekhukhune II's attacks and as a result many prefered to scatter about in the nearby mountain caves. This created problems for Trumpelmann who had to travel from one mountain to the other to cater for the spiritual needs of his followers. ${ }^{28}$ The fighting amongst Pedi factions at misison stations neutralised them as centres of Berlin missionary activity. The missionaries were therefore no longer effective in carrying out their mission work.

Following the indecisive outcome of the war between Sekhukhune II and Malekutu II, the former continued to launch attacks on minor Pedi chiefs in the Middelburg district who had not yet declared their loyalty to him. For instance, during a joint military operation with Chief Nkwana, he easily rooted out the Bakwena under Chief Nkonyaletse. After that sporadic fighting continued unabated until the occupation of Lydenburg by British forces under Sir Redvers Bullers in September $1900 .^{29}$

\section{Sekhukhune II's supporters undermine the authority of the BMS at Botshabelo}

The outbreak of Anglo-Boer War did not only create zones of war in Sekhukhuneland among Pedi chiefs and at Lobethal mission station between Sekhukhune II and Malekutu II, but it also adversely affected the Berlin missionary enterprise at Botshabelo among the Pedi. Sekhukhune II refrained from using military force to destabilise Botshabelo mission station in order not to antagonise both the British and Boer military authorities. Both authorities wanted to secure the area for military strategic reasons against each other. Nonetheless, Sekhukhune II sent his scouts to quietly monitor and recruit Pedi Christians at Botshabelo to support his goal of re-uniting all the Pedi under the Sekhukhune House ${ }^{30}$.

Superintendent C.T. Nauhaus and his colleagues attempted to establish and maintain the neutrality of the Botshabelo Christian community in the raging conflicts in the eastern Transvaal. However, the British and Boer forces displayed early interest in Botshabelo - especially Fort Merensky and similar but smaller forts erected on the Botshabelo mission farm. Missionary Merensky and the Pedi Christians built Fort Merensky (initially named Fort Wilhelm) to defend themselves against unfriendly local communities. The fort was built on a summit of a high knoll with a steep ascent to it on all sides. "W1 "Walls fifteen high and two feet thick, pierced with loop-

\footnotetext{
$27 \quad$ K 34,120/997(7), Motubatse Vol 7, p 746.

28 BMB, October 1901, pp 376-377.

29 H.O. Monnig,'The Baroka Ba Nkwana,' African Studies, Vol 22, No 4, 1944; and P. Warwick, Black People and the South African War, 1899-1902 (CUP: Cambridge, 1983), p 100.

$30 \quad$ K 34,120/997(7), Vol 7, p 749.

$31 \quad$ P. Delius, The Land Belongs to Us: The Pedi polity, the Boers and the British in the nineteenth century Transvaal (Ravan: Johannesburg, 1983), p 160.
} 


\section{Malunga}

holes and built of iron stone, enclose a space of seven yards square, there are flank defences and a turret over the entrance, which gives a clear view of the surrounding country.",32

The fort had five watch towers: the main tower, which was the highest (about 10 metres high), plus four corner towers. From these towers sentries could keep a sharp lookout for enemies $^{33}$. Again in the centre of the villages, the Pedi Christians had erected similar but smaller forts wherein children and women could find refuge in the event of war. Other smaller forts were also erected at strategic points on the hills surrounding the mission farm in order to cover the different approaches. ${ }^{34}$

In addition, Botshabelo mission station had European style dwelling houses, a good water supply, trading stores and workshops. The latter could be very useful for ox-wagon building and repair works. Moreso, Pedi Christian artisans trained at the mission station could be effectively used by the warring sides. Thus Botshabelo had the potential of serving as an important military base for both sides in the eastern Transvaal. ${ }^{35}$

The Boer military authorities were the first to make a move on Botshabelo. On 30 September 1899, Nauhaus reported that 82 Pedi Christians had been forced to join the war with three ox-wagons loaded with food confiscated from the mission station. Again 240 Botshabelo residents were commandeered to work on Boer farms or to serve as wagon drivers with the war transport ${ }^{36}$. These incidents angered the Botshabelo tenants who expressed contempt for the missionaries for failing to organise military resistance to the Boer forces. Henceforth warring parties would subject the tenants to all sorts of humiliation whenever they felt the need to do so.

There is no doubt that the Botsheblo tenants could have offered some formidable resistance to any invaders. Already in 1865 , the ZAR had permitted Pedi Christians at Botshabelo to own firearms and ammunition. The permission was granted on condition that the Pedi Christians would not go about with guns outside the mission station. Merensky and later Nauhaus were personally held responsible for the safe keeping of the guns. Another condition was that tenants were expected to assist the ZAR in the event of attacks on the Boers by African chiefs ${ }^{37}$. By 1896 due to increasing confrontation among Pedi chiefs, Botshabelo Christians had more than 300 guns. The Pedi Christians had learnt from the missionaries not only the art of shooting, but also the art of repairing the guns. ${ }^{38}$

During the war Botsheblo was literally turned into a military camp. The Boer soldiers occupied the northern part while the British soldiers occupied the southern part of the mission station. Often Pedi Christians were caught in the crossfire as the warring parties attempted to gain control of the mission station with its fort. Whereas both parties vied for the support of the Pedi

BMB, September 1879, p 217; and E. Keyter, 'Rescued from Oblivion,' The South African Panorama, Vol 32, No 12, p 39.

BMB, 1866, p 220.

34. BMB, 1868, p 332.

35 BMB, October 1899, p 318.

36 SS 67,R593/65, A. Merenssky to M.W. Pretorius, Botshabelo, 20.5.1865.

37 Ibid.

38 T.S. van Rooyen, 'Die Verhouding tussen die Boere, Engelse en Naturelle in die Geskiedenis van die Oos-Transvaal tot 1882' (Argief Jaarboek vir Suid-Afrikaanse Geskiedenis, 14/1, 1951); and SS 6064,R1826/96, Nauhaus to Erasmus, 11.12.1896.
} 
Christians, neither was prepared to protect them against the other party. ${ }^{39}$ The missionaries and their families were restricted to the confines of their mission houses and church. They were not allowed to visit outstations. In this regard, the missionary Esselen reported to the Annual General Meeting of the Southern Transvaal Synod that missionaries at Botsheblo were prohibited from moving more than 1000 paces away from their houses. Any missionary who ventured to walk out of this parameter was in danger of being accused as a spy. In addition, all roads leading to and from Botsheblo were closed and no civilian traffic was allowed in the immediate vicinity of Botshabelo ${ }^{40}$.

For the maintenance of their troops, both the British and Boer forces frequently raided and looted the mission station trading stores and grain storage. The besieging military forces also bought all available cattle, horses and sheep from Botshabelo tenants at their own imposed prices " only a single, half blind horse remained at the mission station ". 41 This adversely affected the material position of both the missionaries and Pedi Christians at Botshabelo since their wealth was largely invested in livestock.

Sekhukhune II's scouts exploited this deprivation to canvass support from the disillusioned Pedi Christians for their chief. They argued that support for Sekhukhune II would ensure his increased and better military capacity to reclaim some of the confiscated livestock when the time was opportune. The failure of the Berlin missionaries to offer some kind of protection to the Pedi Christians caused a growing number of the latter to declare their support for Sekhukhune II. ${ }^{42}$ This represented a psychological victory for Sekhukhune II over his Pedi rivals. Again, although no evidence could be found, the support of Pedi Christians for Sekhukhune II appear to be a confirmation that they would have been prepared to take up arms to defend their livestock and property from confiscation if the Berlin authorities were prepared to defend their neutrality against the British and Boer forces by force of arms.

The occupation of Lydenburg by the British forces in September 1900 strengthened their military position over the Boer forces in the eastern Transvaal. The Boer forces were subjected under severe attacks at Botshabelo and eventually withdrew. Henceforth they embarked on guerrilla warfare. When the British forces took control of Botshabelo, they accused the Berlin missionaries of siding with the Boers. Apparently this was due to the information received by the British military intelligence that Johannes Trumpelmann, son of the missionary G. Trumpelmann and Alexander Beuster, son H. Beuster (a German trader at Botshabelo) were fighting on the side of the Boer forces. ${ }^{43}$

The British forces targeted German missionaries at Botshabelo and Lydenburg (Lobenthal and Arkona had become non-functional as a result of the inter-communal wars by Pedi chiefs). Word soon spread among the Pedi Christians that it was safer to re-settle on areas under Pedi chiefs. Thus between 1900 and 1902 there was a steady movement of Pedi Christians from Botshabelo and Lydenburg mission stations to areas controlled by Pedi chiefs. ${ }^{44}$ To make matters

\footnotetext{
$39 \quad$ BMB, March 1901, p 118.

$40 \quad$ BMB, July 1901, p 271.

41 BMB, March 1901, p 118.

42 SNA 53 271/02, Winter to Hogge, n.d.

43 SNA $10,152 / 02$, Hogge to Lagden, n.d.

44 SNA 50,161/02, Winter to Hogge, 2.9.1902. 


\section{Malunga}

worse, on 9 July 1900, the British military authorities arrested missionaries Nauhaus, Trumpelmann, W. Tauret, M. Markert, the German trader Beuster and three other Germans living at Botshabelo. They were accused of supporting the Boer guerrilla commandos and interned at Middelburg. The representative of the German Consul in Pretoria, however, later bailed out the German missionaries for the sum of approximately $£ 20000$. They were allowed to stay with friends at Middelburg. ${ }^{45}$

The occupying British forces also began to use Pedi Christians at Botshabelo for carpentry and ox-wagon repair to promote their military campaigns. Initially, both sides had compelled the Pedi Christians to render services without pay. However, as the war progressed, the British arranged for the payment of all the Pedi Christians serving under them. This had the impact of luring the Pedi Christians to desert the Boer forces in greater numbers to seek employment with British forces. In this way a number of Pedi Christians gained a means of making a living ${ }^{46}$.

The absence of the missionaries at Botshabelo brought about a climate of anarchy. The British soldiers looted the houses of the missionaries, the church altar was broken and holy bread was scattered in the church. The British soldiers also spread the information among the Pedi Christians that the missionaries would not be allowed to return to their mission stations. This unleashed a spirit of licentiousness and disorder began to prevail at Botshabelo. There was no missionary or Council of Elders to enforce the rules and regulations of the mission station. ${ }^{47}$ At this stage supporters of Sekhukhune II were openly calling upon and urging their fellow Pedi Christians to take up arms and help the British soldiers in rounding up the Boer guerrilla groups.

\section{British military authorities enlist Pedi support against Boer guerrilla forces}

When Buller occupied Lydenburg in September 1900, he ordered the immediate cessation of all Pedi inter-communal fighting in Sekhukhuneland, the Middelburg and Lydenburg districts. Richmond Haigh was appointed Acting Commissioner and stationed at Magnets Heights. Sekhukhune II, Malekutu II and Kgolane attempted to gain the favour of the British authorities by blaming one another for the inter-communal wars in Sekhukhuneland. Winter sent a report, on behalf of Kgolane, to Haigh in which he recounted his version of the causes of the inter-communal wars. He blamed Sekhukhune II for the loss of Pedi lives and destruction of property. Malekutu II called upon the British authorities to unseat Sekhukhune II as the Pedi paramount chief. He maintained that Sekhukhune II had mobilised his army against Malekutu II, Kgolane and other supporters of Erasmus in order to impose his paramountcy on the Pedi people. ${ }^{48}$

However, Haigh's immediate task was not only to halt hostilities among Pedi rival groups but also gain their support against the Boer guerrillas operating in the eastern Transvaal. Accordingly Haigh formed a small task force to which leading supporters of Sekhukhune II, Malekutu II and Kgolane were conscripted. They were trained in intelligence work as well as hunting down Boer guerrilla groups. The task force was to eliminate Boer guerrilla areas of

\footnotetext{
$45 \quad$ BMB, October 1901, pp 341-351.

$46 \quad$ BMB, August 1901, p 342.

47 BMB, October 1901, pp 453-454.

48 Pretoria Archives Depository: archives of the Colonial Secretary (hereinafter CS) 2,226/01, Quarrel between Malekutu and Sekhukhune and other enclosures, 20.12.1900.
} 
operation and deprive them of grain and livestock. ${ }^{49}$ The British also formed similar task forces elsewhere in the South African Republic. This was in keeping with the British policy of clearing the country districts by burning houses and crops so as to deprive the Boer commandos of food and lodging. ${ }^{50}$

The British army relied on the active involvement of the Pedi in a variety of ways. The Pedi were employed to round up cattle of Boer families and bring these into the garrison towns in return for a share of the livestock apprehended. Thus in April 1901, General Walter Kitchener arranged with Sekhukhune II to take over all the Boer cattle driven by the British troops in his direction and to round them up in Geluks Location. Sekhukhune II was then allowed to keep half of the number of cattle captured. General Kitchener also entered into a similar agreement with Malekutu II and Chief Micha Dinkwanyane. ${ }^{11}$ Pedi farm workers who paid allegiance to Sekhukhune II also launched attacks against Boers in the Ohrigstad area. Their intimate knowledge of the locality enabled them to plunder the surrounding farms. As a result many Boer families deserted their farms ${ }^{52}$.

Further, Boer families from the Lydenburg district were rounded up and taken to specific checkpoints where they were kept under Pedi guard. At one stage Haigh reported that Sekhukhune II was having 10 Boer men, 10 women and 34 children waiting for General Kitchener to arrange for their transfer to a military camp. ${ }^{53}$ Again to curtail the movement of the Boer commandos and to deny them access to food supplies and fresh horses, Pedi chiefs were encouraged to thwart any attempts by guerrillas to enter their areas. On British military orders Malekutu II effectively prevented the Boers from re-entering the Middelburg district. He achieved this by organising his followers into closely-knit guarded settlements and patrols, which hindered Boer incursions into the Middelburg district. Chief Dinkwanyane, a subordinate chief of Sekhukhune II, was ordered to seal off the strategic Waterval Valley. This act blocked all the wagon routes and thereby prevented the Boers from transporting the much-needed grain from Ohrigstad Valley to Dullstroom and Roos Senekal to the commandos on the Highveld. ${ }^{54}$

In July 1901 a group of about 400 Pedi warriors, heavily armed with Lee Metford rifles, cornered 14 Boer families on the farm Suikerbosplaat in the Middleburg district. This group of Pedi warriors owed allegiance to Sekhukhune II. For some months these 14 Boer families had successfully managed to escape arrest by a contingent of national scouts, English soldiers and Africans under the command of Gert Vosloo. The Boer families had about 700 cattle and 200 horses, which were intended as supplies for the Boer commandos. They were then disarmed by the Pedi warriors and shepherded to Phokoane. ${ }^{55}$

From Phokoane they were taken to Sekhukhune II for prosecution. Sekhukhune II took possession of their rifles, cattle and horses. They were held as prisoners for 21 days and eventually

\footnotetext{
49 SNA 8 194/01, R. Haigh to D. Henderson, Pretoria, 22.9.1901.

50 D. Denoon, Southern Africa since 1800 (Longman: London, 1984), p 104.

51 SNA 13,1569/02 Gen. Walter Kitchener to Sekhukhune II, 10.4.1901.

$52 \quad$ K 34,120/965(6), Motubatse, Vol 2, p 515.

53 SNA 1,62/01, Report on the state of affairs in Sekukuni's country, Haigh to Henderson, n.d.

54 SNA 8,210/01, Captain A.W. Baird to Henderson, n.d.

55 Bethesda Mission Station, Miscellaneous Collection (hereinafter A) 194. Sworn declaration by C.V.

Breytenbach, August 1902.
} 
handed over to the British at the Lydenburg garrison. A few days later they were transferred to Machadodorp. Here women and children were separated from the men. The latter were later sent to India together with other captured Boer soldiers. The women and children were sent to Balmoral concentration camp where they were kept until July 1902 when they were returned to their homes ${ }^{56}$.

The co-operation between the British army and the Pedi enabled the latter to meet some of their needs and aspirations. For instance, the Pedi were in a position to recover most of the cattle they had were deprived before 1899 by some unscrupulous local republican government officials and farmers. The British military authorities commandeered about 600 cattle of Erasmus into Sekhukhuneland. These cattle were then confiscated by Sekhukhune II who regarded them as a reward for the role played by his followers in tracking down Boer guerrilla groups. ${ }^{57}$

On the other hand, Pedi involvement in the Anglo-Boer War brought misery and sufferings to those who were conscripted by the Boer commandos as farm labourers, wagon-drivers, scouts and guides. With the collapse of the Boer commandos, these Pedi were held prisoners in diseaseridden concentration camps. Motubatse has estimated that close to 500 Pedi died in British concentration camps. ${ }^{58}$

\section{Demand to be recognised as the sole paramount chief of the Pedi}

Having consolidated his authority in the Pedi heartland, Sekhukhune II now demanded the payment of one shilling by all Pedi as proof of their allegiance to the Sekhukhune House. The aim was apparently to demonstrate that Pedi loyalty and allegiance was to its paramountcy and not to any colonial government or white landlords. In September 1901, Haigh informed Henderson that the majority of the Pedi were willing to pay this tribute. ${ }^{59}$

In his report on the state of affairs in Sekhukhuneland, Haigh reported that chiefs Phasoane, Nkoane, Mankopane, Maserumula, Mokomane and Shopiane recognised Sekhukhune II as paramount chief of the Pedi. Chiefs Mphahlele and Micha Dinkwanyane recognised Sekhukhune II as the head but enjoyed a considerable amont of autonomy from him. Besides these chiefs, there were many other petty chiefs and headmen who accepted Sekhukhune II's paramountcy ${ }^{60}$. The Sekhukhune party demanded of the British authorities that all farms between the Olifants and Steelpoort rivers occupied by various companies be returned to the Pedi. They also demanded that Winter, Kgolane's political benefactor and agent of one of the powerful land companies with interests in their locality be expelled from the Pedi territory ${ }^{61}$.

Haigh estimated the fighting strength of Sekhukhune II's army at 6000 men. Of these 500 would carry modern rifles and perhaps 1500 would have old-fashioned shooting weapons. It was also reported that Sekhukhune II had obtained, from an unknown source, a large supply of small arms and ammunition from the Ohrigstad valley direction. Sekhukhune II hoped to subjugate

Ibid.

57 SNA 47,1569/02, Minutes of the meeting held at Middelburg with native chiefs, 6.10.1902.

$58 \quad$ K 34,120/1056(36), Motubatse, Vol 36, p 156.

59 SNA 194/01, Haigh to Henderson, 22.9.1901.

60 SNA 1,62/01, Report on the state of affairs in Sekukuni's country, n.d.

61 P. Warwick, Black People and the South African War (Ravan: Johannesburg, 1983), p 102.
} 
Malekutu II, Kgolane and their allied chiefs in order to gain complete control over Pedi affairs in the eastern Transvaal. Consequently he was not impressed by the British administration order stopping all fighting in the area. Sekhukhune II's senior councillors, namely Thorometsane, Komane and Phasoane were in favour of disregarding the British military order.

On the other hand, chiefs under Malekutu II, namely Kgolane, Marishane, Tisane and other petty chiefs were reportedly satisfied to be under British rule and protection. Malekutu's fighting strength was estimated to be about 4000 men and nearly half of these would be armed with some kind of shooting weapon ${ }^{62}$. Under these conditions, Sekhukhune II suspected that defying the British military order of cessation of hostilities might bring the combined forces of the British and Malekutu II against him. For this reason, Sekhukhune II disregarded the advice of his senior councillors and decided to abide by the British order.

Gradually the new British administration became more sympathetic to Malekutu II and Kgolane. Winter ably presented the position of the latter to the British authorities. Further, unlike Sekhukhune II, Malekutu II and Kgolane did not attach many strings to their military alliance with the British against the Boers ${ }^{63}$. When Haigh urged Sekhukhune II to allow Kgolane and his followers to re-settle in Geluks Location, the Pedi paramount chief refused. Instead he accused Haigh of interference in Pedi internal affairs. Haigh then arranged for grain to be distributed among Kgolane's people who had no land to plough and no cattle to barter for food ${ }^{64}$.

The Sekhukhune party supported their claims for more land and less colonial interference in Pedi affairs by maintaining that they had driven the Boers from the Pedi heartland before the arrival of British troops; that they were allies and not British subjects; and that they had provided the British army with valuable military intelligence. Such loyalty they thought merited compensation. ${ }^{65}$ The Pedi had assisted the British in the hope of regaining lands lost to the ZAR.

Sekhukhune II vaguely threatened to withhold Pedi labour in the Lydenburg district if his demands for autonomy were not met. It would appear that he deliberately allowed this threat to be fuelled by his councillors and chiefs. In reality, however, he did not have the means to enforce his instructions on all the Pedi. Indeed at this time, the Pedi desperately needed employment on Boer farms in order to avoid starvation. Thus he could not have risked alienating his followers and driving them into the arms of his rivals by trying to enforce his instructions.

Towards the end of the war, the imperial authorities moved quickly to disentangle themselves from the statements of Lord Salisbury and Chamberlain regarding the future political rights of Africans in South Africa. Lord Kitchener informed the leadership of the former ZAR and Orange Free State that the British government would not grant the franchise to Africans in the two republics before representative government was granted. Instead the British would strive to entrench the white race predominance in South Africa. ${ }^{66}$

\footnotetext{
62 SNA $162 / 01$, Haigh to Henderson, n.d.

63 SNA 3,187/01, Haigh to Henderson, 16.10.1901.

64 SNA 15,2103/01, A.W. Baird to Henderson, 12.11.1901.

65 N. Worden, The Making of Modern South Africa: Conquest, Segregation and Apartheid (Blackwell: Oxford and Cambridge, 1994), p 29. 


\section{Malunga}

On the 31 May 1902, the Treaty of Vereeniging brought the Anglo-Boer War to an end. Among others, it was agreed that the Transvaal and the Orange River Colony would be British colonies. Clause 8 of the Treaty stated that "The question of granting the franchise to natives will not be decided until after the introduction of self-government." ${ }^{67}$ Self-government actually meant government by the Boers who would not allow Africans equal political rights. Thus the Pedi as well as other Africans elsewhere in the two former republics felt betrayed for they had trusted promises by imperial officials.

Dennon maintains that the British authorities abandoned their alliance with the Africans because the interests of the latter were incompatible with British interests. Britain required the Boers as a collaborating group in South Africa. At this stage Africans were of little real use as a political and economic collaborating group. To promote social change in favour of Africans would have meant preparing the ground for continued strife between Briton and Boer in South Africa. ${ }^{68}$ Further, in favour of the British was also the fact that unlike the Boers, Africans were not united and organised as a military and political pressure group to challenge British superiority successfully. The successes gained by the Afrikaners after 1902 in the economic or political field can be ascribed to this attitude of the British.

After the conclusion of the Treaty of Vereeniging, a British civilian government was established in the Transvaal. Sir Godfrey Lagden became the Secretary for Native Affairs. W.A. Knight and W.E. Peachy were appointed as sub-Native Commissioners under Hogge to serve in Sekhukhuneland and Middelburg respectively.

\section{Land ownership, Labour supply and ownership of captured livestock}

In the eastern Transvaal, as was indeed the case throughout the Transvaal, the return to civilian rule brought to the fore the vexing question of land ownership, labour supply and ownership of livestock captured during the war by both the Pedi and Boers. Impressions had been created by the British authorities before and during war that the object of the war was to restore Africans to their old lands. In this instance, Hogge told Lagden that the Pedi were resisting attempts to remove them from land previously occupied by the Boers. This was because the Pedi had built new houses, and planted crops that provided them with a source of cash income when sold at a public market. The harvests also met the consumption needs of Pedi households ${ }^{69}$. Sekhukhune II also felt entitled to some kind of reward, in the form of additional lands for his people. This would allow for more stock farming and ploughing. ${ }^{70}$

The Boers, on the other hand, were dissatisfied with British lack of action against the Pedi who were reluctant to vacate the farms left vacant by Boer families during the war. They also claimed that Sekhukhune II had the capacity to withhold farm labour. If this happened, the

British Parliamentary Papers (hereinafter C) 1163 - 1902. Further correspondence relating to affairs in South Africa, July 1902, enclosure in No 55, Gen. Lord Kitchener to Mr. Broderick, 1.6.1902, pp 155-156. 
rehabilitation of white agriculture that was given priority by the new administration would not materialise. They therefore urged that military action be taken against Sekhukhune II. ${ }^{71}$

The issue of Boer cattle captured by the Pedi during the war also strained the relationships between Boer and Pedi. The Pedi felt justified in keeping captured Boer livestock in terms of their "gentleman's agreement" with General Kitchener. On the other hand, the Boers could not comprehend why the "savage Pedi" were being allowed to keep livestock belonging to a "civilised white community". Hogge urged the Secretary for Native Affairs to issue a directive to settle this thorny issue ${ }^{72}$.

In September 1902, the Transvaal government issued a directive allowing the farmers to retrieve livestock captured from them by the Pedi. However, such livestock could only be retrieved through an official of the Native Commissioner's office. This caused uproar throughout the eastern Transvaal. ${ }^{73}$ Sekhukhune II and other leading Pedi chiefs gained the impression that the British had betrayed them by unilaterally opting out of "a gentleman agreement" that had been entered into by both sides. To correct this error, the government later allowed the Pedi, likewise, to claim back their livestock from the farmers through the office of the Native Commissioner ${ }^{74}$. However, the damage had been done and Sekhukhune II and his followers began to doubt the impartiality of the British in dealing with the Pedi and the Boers.

However, this arrangement had to be abandoned because the Boers refused to hand over livestock to Pedi claimants. Sir Lagden then instructed magistrates to encourage the Pedi to surrender Boer livestock by compensating them financially for the animals received. However, no Pedi was prepared to exchange livestock for cash. Eventually the administration left many cases of livestock ownership to be settled by courts. It was through this procedure that some of the Boers, through their legal representatives, successfully contested their claims.

\section{The Schoonrod Conference, $\mathbf{1 9 0 2}$}

In September 1902, the Secretary for Native Affairs issued a directive to all Native Commissioners in the Transvaal. Native Commissioners were to arrange meetings with the chiefs to explain the policy position of the new administration with regard to African demands for more land, Africans living on Boer farms and more importantly the possession of firearms. Thus, on the 6 September 1902 the Schoonrod Conference was organised for Sekhukhuneland. The attendants were Hogge, Knight, Winter, Sekhukhune II together with 44 chiefs and 39 headman - all paying their allegiance to the Pedi paramount. ${ }^{75}$

The Native Commissioner had insisted that all chiefs and headman under Sekhukhune II should attend the conference because he wanted to ensure that the government's policy position on several important matters would reach the Pedi people. ${ }^{76}$ Ironically the large numbers of conference

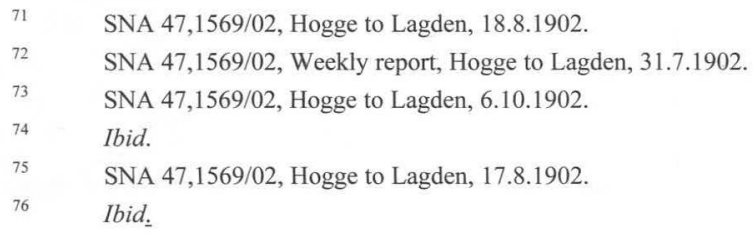


attendants also served to indicate the popularity of Sekhukhune II's paramountcy amongst the Pedi.

Almost every Pedi speaker referred to the question of more land and the extension of their locations. Hogge later reflected that it appeared that the Sekhukhune party, unlike in the past, was no longer demanding the right to self-rule. ${ }^{77}$ Hogge responded to demands for more land by the Pedi. He indicated that there was a general demand for more land by Africans throughout the Transvaal. He acknowledged that the former ZAR had in 1881 occupied large tracks of Pedi territory by conquest. These lands were subsequently sold to farmers and land companies. However, in keeping with the terms of the Treaty of Vereeniging, the new administration could not dispossess the farmers and private companies of their lands. ${ }^{78} \mathrm{He}$ stressed that the government required more time to study land distribution and occupation by Africans throughout the Transvaal before taking a final decision.

The second problem was closely associated with the first one. It concerned Pedi workers living on Boer farms. Hogge indicated that there was a general impression amongst the Pedi farm workers that the defeat of the former ZAR also meant farm dispossession. This impression had further gained support by the alleged order from Sekhukhune II to the Pedi to refuse employment by farmers. Hogge made it known that in terms of the Treaty of Veering, the Boers and prisoners of war that accepted the terms of surrender were allowed to return to their farms. This meant that the farms still belonged to the Boers. Consequently Peed squatters on Boer farms were still subjected to Law No. 21 of 1885, also known as the Plakkers Wet (Squatters Act). ${ }^{79}$

The government's response to the demand for additional land was unacceptable to Sekhukhune II and his people. Sekhukhune II argued that the Pedi had entered into a military alliance with the British on the understanding that the Boers would be driven out the Eastern Transvaal. The evacuated farms would then be made available to the Pedi for occupation.

The trickiest issue discussed at the conference was the question of disarming the Pedi. The Arms and Ammunition Ordinance No. 17 of 1902 ordered the surrender of all arms and ammunition to the government by all people in the Transvaal. Opponents of Sekhukhune II suspected that the latter would resist the order. Winter expressed the opinion that the Pedi would give up their guns only if it was made abundantly clear that the alternative would be war with the British. Consequently as a precautionary measure, Hogge arranged for 100 members of South African Constabulary to be present when the disarmament order was issued at the conference. ${ }^{80}$

In presenting the disarmament order Hogge emphasised that the Ordinance affected every African, Boer and Briton in the country. He indicated that henceforth anybody who wished to possess a firearm was to obtain a licence. Such a licence could be issued through the recommendation of either a Native Commissioner in the case of Africans or a magistrate in the case of Whites ${ }^{81}$. Henceforth the army and the South African Constabulary would be responsible for the maintenance of law and order. Hogge appealed to Sekhukhune II and his followers to comply with

SNA 47,1569/02, Hogge to Lagden, 8.9.1902.

SNA 47,1569/02, Conference held at Schoonrood, Sekukuni's Location, 6.9.1902.

Ibid.

SNA 47,1569/02, Weekly report, Hogge to Lagden, 18.8.1902; and SNA 50,161/02, Winter to Hogge, 2.9.1902.

SNA 47,1569/02, Minutes of the meeting held at Schoonrood, 5.9.1902. 
the terms of the Ordinance. He warned that failure to surrender all arms and ammunition would certainly force the government to take military action against them.

The Native Commissioner indicated that he was prepared to recommend the granting of firearm licences to chiefs and headmen, but only on condition all guns were first surrendered. Knight was entrusted with the responsibility of receiving surrendered guns and ammunition. A receipt would be issued and on it would be stated the price at which the gun o ammunition was valued. Compensation would be paid out within six months. ${ }^{82}$

Evaluation of Metfords, Mausers, Martinis and any other rifles were set as follows: $£ 315 \mathrm{~s}$ 0d for those in good shape, $£ 3$ 0s 0d for those in bad shape. Muzzleloaders were evaluated from $£ 11$ downward according to quality. Ammunition for various types of guns was valued at $7 \mathrm{~s} 6 \mathrm{~d}$ per 100 if in good order and 5s per 100 if in poor order. Between them Hogge and Knight agreed that for gun a handed in by a chief or one to whom a licence to carry firearms was sure to be given, a fairly high value was to be placed on it. ${ }^{83}$

Hogge was quick to stress that he would immediately proceeded to the Middelburg district to announce Ordinance No. 17 to Malekutu II and his sub-chiefs. This was an attempt to reassure Sekhukhune II that his old rivals would also be disarmed. The Native Commissioner also gave vague assurances that there would be no large scale general re-arming of the Boers. However, before the end of 1902, almost all Boers on farms in the eastern Transvaal were licensed to carry firearms.

After a day's consultation with his sub-chiefs and headmen, Sekhukhune II finally accepted the terms of Ordinance No.17. He promised the Native Commissioner that his people would surrender all their guns and ammunition to Knight within a period of one month. Individuals who resisted the order would have to face arrest and imprisonment. ${ }^{84}$

On 10 September 1902, Hogge and Peachy proceeded to Mamone to explain the terms of Ordinance No. 17. Present were Malekutu II, Kgolane, Matseba and a few subordinate chiefs and headmen. Winter acted as interpreter. As expected Malekutu II accepted Ordinance No. 17 on condition he would be protected from enemy attack. The Native Commissioner undertook to ensure that the South African Constabulary would protect Malekutu II and his followers. Peachey started to receive guns and ammunition at Mamone from the 11 September on similar conditions as laid out to Sekhukhune II. ${ }^{85}$

Towards the end of October 1902, the Resident Magistrate of Lydenburg reported that arms surrendered in his district numbered between 10000 and 11000 . Included in this number were 4321 firearms that had been reluctantly surrendered by the followers of Sekhukhune II. ${ }^{86}$ The disarmament of the Pedi in 1902 marked the final collapse of Pedi resistance to colonisation.

Kgolane's request, supported by Winter, to be returned to Masehleng from where he had been evicted by Sekhukhune II in June 1890 was accepted by the Transvaal government.

\begin{tabular}{ll}
\hline 82 & Ibid. \\
83 & SNA 47,1569/02, Hogge to Lagden, 17.9.1902. \\
84 & SNA 47,1569/02, Hogge to Lagden, 18.9.1902. \\
85 & SNA 47,1569/02, Meeting held at Chief Malekutu's Kraal, 10.9.1902. \\
86 & SNA 47,1569/02, Weekly report, Hogge to Lagden, 30.9.1902. \\
Scientia & Militaria 31(1) \\
2003 &
\end{tabular}




\section{Malunga}

Malekutu II, whose political image had been enhanced by giving Kgolane refuge, was opposed to this decision. He was further convinced that so long as Kgolane remained with him, Sekhukhune II would not be tempted to attack the combined forces of the two chiefs. Despite the protest by Malekutu II, Kgolane and 780 of his followers were re-settled at Masehleng. Subsequently, however, Kgolane moved on to Madibeng that was further away from Sekhukhune. ${ }^{87}$

After the war, displaced Pedi communities and the returning Pedi refugees missed the opportunity to cultivate enough land for their needs during the season ahead. Lack of seeds and implements such as ploughs and hoes made cultivation of fields difficult. There was also a scarcity of draught animals because cattle diseases such as lung sickness destroyed most of them. To overcome the problem of starvation among the Pedi, the Native Refugee Department organised regional grain depots where people in difficult circumstances could buy mealies at $£ 1$ per bag ${ }^{88}$.

\section{Conclusion}

To conclude, the Anglo-Boer War enabled Pedi chiefs and Sekhukhune II in particular, to destabilise, undermine and then drastically reduce the influence of the Berlin Mission Society and the Bapedi Lutheran Church among Pedi Christians. This in turn enabled them to reclaim, to some great extent, the political and social responsibilities they had lost over Pedi Christians. Again the war marked an end to the long process of confrontation between the Sekhukhune House and the ZAR in the eastern Transvaal. The rivalry of various Pedi factions over the question of the Pedi paramountcy ended indecisively. In the process hundred of Pedi civilians were killed. Many more especially those who had being compelled to work for the Boer forces ended up in concentration camps that were death camps. 